\title{
Simian Malaria at Two Sites in the Brazilian Amazon - II. Vertical Distribution and Frequency of Anopheline Species Inside and Outside the Forest
}

\author{
Ricardo Lourenço-de-Oliveira ${ }^{+}$, Sergio LB Luz
}

Laboratório de Transmissores de Hematozoários, Instituto Oswaldo Cruz, Av. Brasil 4365, 21045-900

Rio de Janeiro, RJ, Brasil

An anopheline survey was carried out in two simian malaria areas in the Brazilian Amazon, Balbina and Samuel, to determine the potential vectors of Plasmodium brasilianum. The most abundant and/or acrodendrophilic anophelines in the forest and the most likely vector were Anopheles mediopunctatus, An. nuneztovari, An. oswaldoi, An. triannulatus and An. shannoni. An. darlingi and An. marajoara were captured essentially in anthropic habitats outside the forest and are unlikely to be involved in the transmission of $\mathrm{P}$. brasilianum among monkeys within the forests and from monkeys to man in their surroundings in the Amazon.

Key words: simian malaria vectors - Anopheles - Culicidae - Plasmodium brasilianum

The simian malaria caused by Plasmodium brasilianum is widespread in the humid forests of Central and South America. Its vector has been discovered only in the Atlantic forest, of southern and southeastern Brazil, where the acrodendrophilic mosquito Anopheles (Kerteszia) cruzii was found naturally infected with the parasite (Deane et al. 1970). An. cruzii does not occur in the Amazon Region where P. brasilianum is suspected to be the cause of a zoonozis (Lal et al. 1988, Arruda et al. 1989). Such a zoonotic malaria vector would need to feed frequently on infected monkeys and humans, mainly indians, rubber gatherers, wood cutters and fishermen, inside the forest or in the surrounding areas.

The current work forms part of a study carried out in two localities in the Brazilian Amazon to describe the zoonotic potential of simian malaria by $P$. brasilianum. The infection rates of this parasite in monkeys from those areas have been published elsewhere (Lourenço-de-Oliveira \& Deane 1995). This paper presents the results of a mosquito survey conducted in those sites to describe the anopheline fauna within the forest and in surrounding cleared areas, as well as anopheline species frequencies near the ground and in the tree canopy.

Suported by $\mathrm{CNPq}$

${ }^{+}$Corresponding author. Fax: +55-21-290.9339

Received 29 February 1996

Accepted 20 May 1996

\section{METHODOLOGY}

The anopheline survey was performed near two hydroelectric plants in the Amazon Basin: Balbina, on the Uatumã River, State of Amazonas (1 ${ }^{\circ} 55^{\prime} \mathrm{S}$ $\left.59^{\circ} 28^{\prime} \mathrm{W}\right)$ and Samuel, on the Jamari River, State of Rondônia ( $8^{\circ} 10^{\prime} \mathrm{S} 62^{\circ} 29^{\prime} \mathrm{W}$ ), Brazil, where $P$. brasilianum was detected in, respectively, $15.8 \%$ and $9.9 \%$ of the primates. Details about these two sites, such as climate, vegetation and fauna are given elsewhere (Lourenço-de-Oliveira \& Deane 1995).

Mosquitoes were caught while biting human or animal baits or by light-trap and identified according to Deane et al. (1947) and Faran and Linthicum (1981). The anopheline captures in Balbina were performed in two periods: 6-30 September 1988 and 18 September to 20 October 1989. Within the forest, anopheline catches were carried out on human bait, from 6 to 9 p.m., at two sites: Base I, on both the west and east margins of the Uatumã River, and Base II, an island in the reservoir about $70 \mathrm{~km}$ from the dam. At Base I anophelines were collected simultaneously from a human bait at ground level and another on a platform in the canopy, at $14 \mathrm{~m}$ above the ground.

For comparison, mosquito captures were also conducted outside the forest, from 27-29 September 1988, in three settlements of the WaimiriAtroari Indian tribe: Cacau, Curiuaú and Maré. In 1989, a total of 424 Waimiri-Atroari lived in 11 settlements near the Balbina forest. The settlements of Cacau and Maré are on the east and west margins of the Camanaú River, with 33 and 37 inhabitants, respectively, while the Curiuaú is on the 
north margin of the Curiuaú River, with 36 residents. The huts are constructed completely of palm leaves or have wooden walls and a roof of palm leaves. Anophelines were captured simultaneously on four human baits, one inside the hut, one immediately outside, one near the forest, and another in the forest, from 6 to 9 p.m., in Cacau and Curiuaú and from 5 to 7 a.m. in Maré. Additionally, a CDC light-trap (Sudia \& Chamberlain 1962) was operated near the rivers and the forest.

In Samuel, anophelines were surveyed from 17 February to 28 March 1989 and from August 1990 to July 1991. Collections were performed at three sites within the Samuel Ecological Station, where platforms were built at 15-17 m above the ground in the canopy of selected trees. The Samuel Ecological Station is an uninhabited portion of primary forest between $8^{\circ} 50^{\prime}$ and $9^{\circ} 04^{\prime} \mathrm{S}$ and $63^{\circ} 08^{\prime}$ ' and $63^{\circ} 19^{\prime} \mathrm{W}$, on the southeast border of the reservoir, $50 \mathrm{~km}$ from the dam and contiguous with the Jamari National Forest. There, anophelines were caught daily, except on rainy nights, from 6 to 9 p.m., on human baits placed simultaneously on the ground and in the canopy.

Additionally, some anophelines were collected from 6 to 8 p.m., between 23-31 July 1991, outside the forest, close to dwellings, at three sites near Samuel: Boca do Rio Novo, Caboclo and Japiim Road. At the first two sites, collections were only on human baits, while at Japiim Road simultaneous catches were performed on man and cow. Only a fisherman's family lives at Boca do Rio Novo, in a wooden house surrounded by the forest, $5 \mathrm{~km}$ from the Samuel dam. During the dry season, Caboclo is a temporary settlement of rubber-gatherers, located $4.5 \mathrm{~km}$ form the dam, with open, wooden huts, covered with palm leaves, surrounded by the forest. Both Boca do Rio Novo and Caboclo are downstream from the dam on the west bank of Jamari River. Anophelines were captured on a human baith close to the dwellings. At Japiim Road anophelines were collected from a human bait and a cow near two wooden houses close to the forest. This road links the village of Itapoã do Oeste to the Japiim stream, a tributary of the Jamari River, south of the Samuel Ecological Station. All collection sites in Balbina and Samuel are shown on a map in Lourenço-de-Oliveira and Deane (1995:333). G test against a null hypothesis was used to compare the occurrence of anopheline species at ground and in the canopy.

\section{RESULTS}

Ten anopheline species were recognized in the surveyed areas of both Balbina and Samuel (Tables I, IV). An. nuneztovari and An. oswaldoi were the most abundant species in Balbina, accounting for more than $70 \%$ of the total. Nine anopheline species were collected within the forest and only two, An. darlingi and An. oswaldoi, at the WaimiriAtroari settlements near Balbina (Table I, Fig. 1). In these anthropic environments only 19

TABLE I

Anopheline mosquitoes caught inside and outside the forest at Balbina, i.e. at three Waimiri-Atroari settlements, State of Amazonas, Brazil, from 6 to 30 September 1988 and 18 September to 20 October 1989

\begin{tabular}{lccc}
\hline \multirow{2}{*}{ Species } & \multicolumn{2}{c}{ Forest } & Total \\
\cline { 2 - 2 } Anopheles nuneztovari Gabaldon & Inside & Outside & 840 \\
Anopheles oswaldoi (Peryassu) & 840 & - & 745 \\
Anopheles (Nys.) spp. $^{\text {An }}$ & 742 & 3 & 300 \\
Anopheles triannulatus (Neiva \& Pinto) $_{\text {Anopheles evansae (Brethes) }}$ & 300 & - & 102 \\
Anopheles mediopunctatus (Theobald) & 102 & - & 74 \\
Anopheles mattogrossensis Lutz \& Neiva & 74 & - & 64 \\
Anopheles darlingi Root & 64 & - & 6 \\
Anopheles peryassui Dyar \& Knab & 6 & 16 & 3 \\
Anopheles shannoni Davis & - & - & 2 \\
Anopheles galvaoi Causey, Deane \& Deane & 2 & - & 1 \\
\hline Total & 1 & 19 & 2152 \\
\hline Man-hours & 2133 & 30 & 178.5 \\
\hline
\end{tabular}

$a$ : damaged specimens; $b$ : the specimens identified by us as An. mediopunctatus probably consists of two related species, neither of which seems to be An. mediopunctatus s.s. (Wilkerson pers. comm., Wilkerson 1988). 
TABLE II

Anopheline mosquitoes caught on human baits and with a CDC light trap at three Waimiri-Atroari settlements Cacau, Maré and Curiuaú - near Balbina's forest, State of Amazonas, from 27 to 29 September 1989

\begin{tabular}{|c|c|c|c|c|c|c|c|}
\hline \multirow[b]{2}{*}{ Species } & \multicolumn{4}{|c|}{ Human baits ${ }^{a}$} & \multicolumn{3}{|c|}{ Light trap } \\
\hline & $\begin{array}{l}\text { Inside } \\
\text { the huts }\end{array}$ & $\begin{array}{c}\text { Near the } \\
\text { huts }\end{array}$ & $\begin{array}{c}\text { Near the } \\
\text { forest }\end{array}$ & $\begin{array}{l}\text { Into the } \\
\text { forest }\end{array}$ & $\begin{array}{l}\text { Near the } \\
\text { river }\end{array}$ & $\begin{array}{c}\text { Near the } \\
\text { florest }\end{array}$ & Total \\
\hline Anopheles darlingi & 8 & 7 & 1 & - & - & - & 16 \\
\hline Anopheles oswaldoi & - & - & - & - & - & 3 & 3 \\
\hline Total & 8 & 7 & 1 & - & - & 3 & 19 \\
\hline Man-hours & 8 & 8 & 4 & 2 & 6 & 2 & 30 \\
\hline
\end{tabular}

$a$ : one person per site.

anopheline mosquitoes were captured during 22 $\mathrm{hr}$ of human baiting and $8 \mathrm{hr}$ of light-trapping (Table II). An. darlingi was collected only outside the forest $(84.2 \%$ of the anophelines from the settlements) while An. oswaldoi was collected both in and outside, although more commonly within the forest. An. darlingi was also the only anopheline caught in and close to huts (Fig. 1).

An. mediopunctatus was far the most common mosquito in Samuel (66.3\% of the total, Table IV). Two other anopheline species were also frequent in the area: An. nuneztovari (13.7\%) and $A n$. shannoni $(9.9 \%)$. An. mediopunctatus was the most common species in the forest (almost $70 \%$ of the total), where it occurred unikely; by contrary $A n$. darlingi was caught almost exclusively in anthropic environments, accounting for $80.6 \%$ of the anophelines captured at Boca do Rio Novo, Caboclo and Japiim Road. An. marajoara was found only outside the forest, primarily attracted by the cow (Table V, Fig. 2).

Most of the anophelines in the forest at Balbina were collected at both levels of the vegetation (Table III, Fig. 3).These included An. nuneztovari, An. oswaldoi and An. triannulatus, which were not significantly more abundant in the canopy $(62.5 \%, 58.5 \%$ and $64.9 \%$ caught in the canopy, respectively $)(\mathrm{Eq}=0.6998)$. An. mediopunctatus was more common in the canopy $(71.9 \%)$, while An. mattogrossensis was captured only at ground level.

Almost $80 \%$ of the anophelines caught within the forest in Samuel were collected in the canopy (Table III). An. oswaldoi was slightly more frequent on the ground while An. mediopunctatus and An. shannoni were the most common canopy feeders (Fig. 3). An. mediopunctatus exhibited the strongest acrodendrophilic behavior in Samuel, with $85.5 \%$ of the females captured in the tree canopy and accounted for $74 \%$ of the total mosquitoes collected at that level.



b

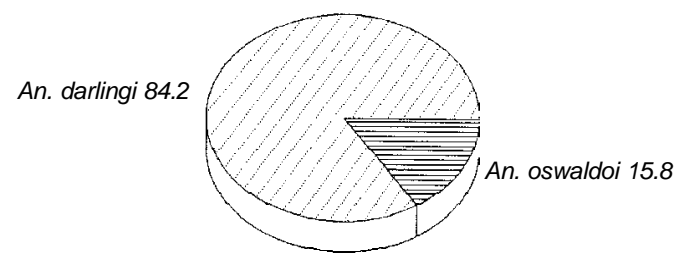

Fig. 1: percentage of each anopheline species collected inside (a) and outside the forest in Balbina (b) i.e. in three WaimiriAtroari settlements, State of Amazonas, Brazil, from 6 to 30 September 1988 and 18 September to 20 October 1989.

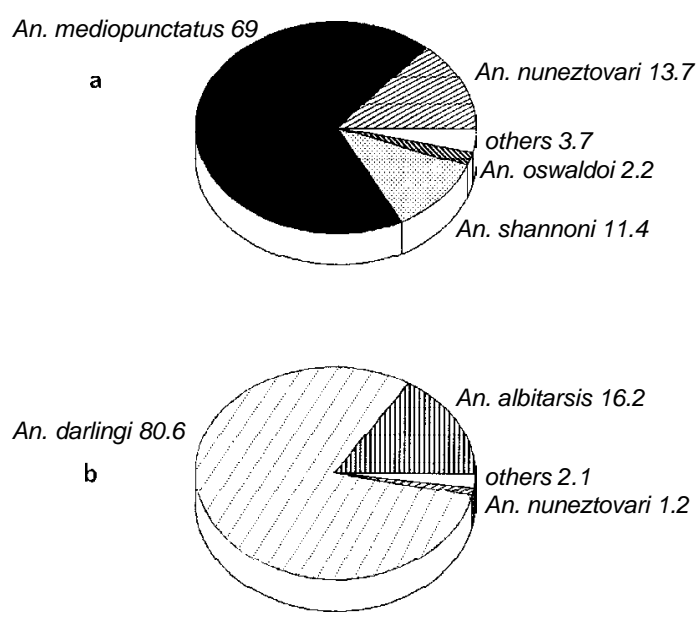

Fig. 2: percentage of each anopheline species collected inside (a) and outside the forest (b) in Samuel, State of Rondônia, Brazil, from 17 February to 28 March 1989 and from August 1990 through July 1991. 

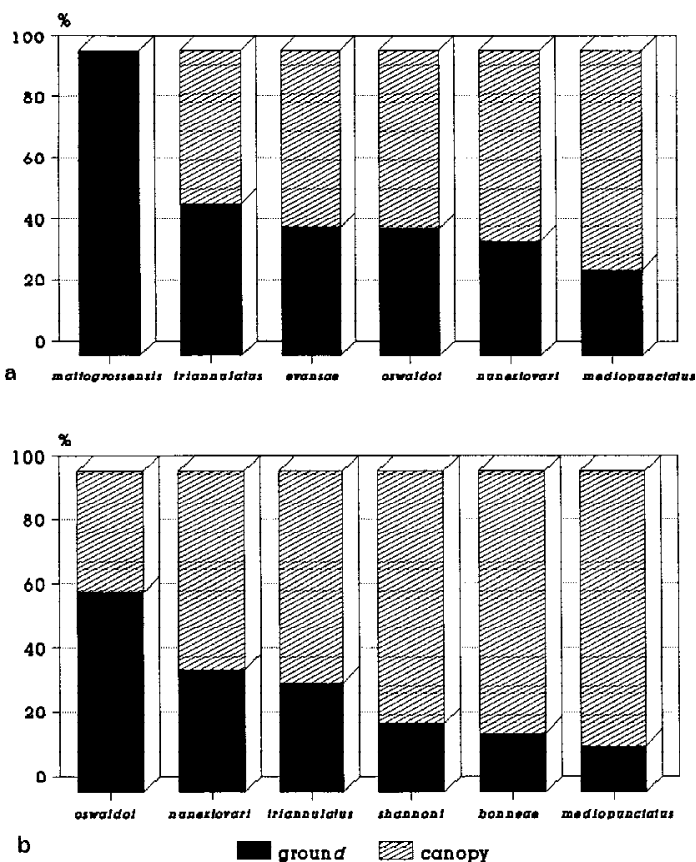

Fig. 3: percentage of each anopheline species caught on humans on the ground and in the forest canopy in Balbina (a) and Samuel (b), respectively in the States of Amazonas and Rondônia, Brazil.

\section{DISCUSSION}

The preference of an anopheline species for feeding in the forest and particularly in the canopy is essential for considering it a potential vector of simian malaria because hosts are primarily arboreal. Attention must be given to the difference between the composition of the anopheline fauna within and outside the forests of Balbina and Samuel. Five species were the most frequent sylvatic anophelines: An. mediopunctatus, An. nuneztovari, An. oswaldoi and An. triannulatus were relatively common at both sites but $A n$. shannoni was abundant only at Samuel. By contrary, An. darlingi predominated outside the jungle. This and other mosquito species found in Balbina and Samuel were rare or absent in the tree canopy, and are unlikely to be involved in the transmission of quartan simian malaria in the Amazon.

An. mediopunctatus has always been associated with the forested environments and has been found in all simian malaria areas in the Amazon (Almeida \& Deane 1970, Ferreira Neto et al. 1970, Deane et al. 1971, Deane 1976, 1992). It was captured only within the forests at both Balbina and Samuel, and was the most common anopheline species at the latter site.

\section{TABLE III}

Capture frequency of anopheline at human baits on the ground and in the forest canopy at $\mathrm{Samuel}^{a}$ and Balbina ${ }^{b}$, respectively, in the States of Rondônia and Amazonas, Brazil

\begin{tabular}{|c|c|c|c|c|}
\hline \multirow{3}{*}{ Species } & \multicolumn{4}{|c|}{ Mosquitoes/man-hour (x10) } \\
\hline & \multicolumn{2}{|c|}{ Samuel } & \multicolumn{2}{|c|}{ Balbina } \\
\hline & ground & canopy & ground & canopy \\
\hline Anopheles darlingi & - & 0.0 & - & - \\
\hline Anopheles evansae & 0.3 & 0.3 & 4.2 & 5.8 \\
\hline Anopheles galvaoi & - & - & 0.1 & - \\
\hline Anopheles nuneztovari & 13.1 & 21.3 & 42.7 & 71.3 \\
\hline Anopheles oswaldoi & 3.8 & 2.3 & 41.7 & 58.8 \\
\hline Anopheles triannulatus & 1.3 & 2.4 & 6.8 & 6.9 \\
\hline Anopheles (Nys) spp. ${ }^{c}$ & 1.6 & 3.3 & 21.0 & 19.3 \\
\hline Anopheles mattogrossensis & - & - & 0.7 & - \\
\hline Anopheles mediopunctatus & 24.2 & 142.9 & 2.4 & 6.4 \\
\hline Anopheles peryassui & - & - & 0.1 & 0.3 \\
\hline Anopheles shannoni & 5.3 & 19.7 & 0.1 & 0.1 \\
\hline Anopheles (Ano.) spp. ${ }^{c}$ & - & 0.0 & - & - \\
\hline Anopheles nimbus & 0.1 & - & - & - \\
\hline Chagasia bonneae & 0.1 & 0.5 & - & - \\
\hline Total & 49.7 & 192.8 & 119.9 & 168.9 \\
\hline Man-hours & 356 & 356 & 76.5 & 72 \\
\hline
\end{tabular}

$a$ : from 17 February to 28 March 1989 and August 1990 to July 1991; $b$ : from 6-30 September 1988 and 18 September to 20 October 1989; $c$ : damaged specimens. 
TABLE IV

Anopheline mosquitoes caught inside and outside the forest at Samuel, State of Rondônia, Brazil, from 17 February to 28 March and from August 1990 to July 1991

\begin{tabular}{lrrr}
\hline & \multicolumn{2}{c}{ Forest } & \multirow{2}{*}{ Total } \\
\cline { 2 - 3 } Species of anophelines & Inside & Outside & 5946 \\
Anopheles mediopunctatus $^{a}$ & 5946 & - & 1231 \\
Anopheles nuneztovari & 1227 & 4 & 889 \\
Anopheles shannoni & 888 & 1 & 275 \\
Anopheles darlingi & 1 & 274 & 216 \\
Anopheles oswaldoi & 216 & - & 180 \\
Anopheles (Nys.) spp. & 174 & 6 & 132 \\
Anopheles triannulatus & 132 & - & 55 \\
Anopheles marajoara Galvão \& Damasceno & - & 55 & 22 \\
Chagasia bonneae Root & 22 & - & 22 \\
Anopheles evansae & 22 & - & 3 \\
Anopheles nimbus (Theobald) & 3 & - & 1 \\
Anopheles (Ano.) spp. & 1 & - & 8972 \\
\hline Total & 8632 & 340 & 728 \\
\hline Man-hours & 712 & 16 & \\
\hline
\end{tabular}

$a$ : the specimens identified by us as An. mediopunctatus probably consists of two related species, neither of which seems to be An. mediopunctatus s.s. (Wilkerson pers. comm., Wilkerson 1988); $b$ : damaged specimens.

\section{TABLE V}

Anopheline mosquitoes caught on human and cow at three settlements - Boca do Rio Novo, Caboclo and Japiim Road - near Samuel's forest, State of Rondônia, from 23 to 31 July 1991

\begin{tabular}{lcccrrr}
\hline \multirow{2}{*}{ Species } & \multicolumn{2}{c}{$\begin{array}{c}\text { Boca do } \\
\text { Rio Novo } \\
\text { Human }\end{array}$} & $\begin{array}{c}\text { Caboclo } \\
\text { Human }\end{array}$ & Human & Cow & Total \\
\cline { 5 - 6 } Anopheles marajoara & - & - & 1 & 54 & 55 \\
Anopheles darlingi & 243 & 25 & 6 & - & 274 \\
Anopheles nuneztovari & 1 & 1 & - & 2 & 4 \\
Anopheles shannoni & - & - & 1 & - & 1 \\
Anopheles (Nys.) spp. & ${ }^{2}$ & 3 & 2 & - & 1 & 6 \\
\hline Total & 247 & 28 & 7 & 57 & 340 \\
\hline Man-hours & 4 & 4 & 6 & 2 & 16 \\
\hline
\end{tabular}

a: damaged specimens.

The presence and abundance of the other four anopheline species in the forest has already been reported for simian malaria areas in the Amazon. In a forested swamp in Porto Nacional, State of Amazonas, Deane et al. (1968) reported that 30\% of the collected anophelines were An. nuneztovari and An. oswaldoi. The latter species was the predominant mosquito in catches performed by Deane et al. (1971) in an enzootic area of simian malaria, Serra do Navio, State of Amapá, accounting for $75.7 \%$ of the anophelines collected, while $A n$. nuneztovari accounted for only $3.7 \%$. An. oswaldoi was the most common anopheline in forested swamp near Tefé, State of Amazonas within the territory of Cacajao calvus, from which $P$. brasilianum was first identified, where it repre- sented $51.3 \%$ of the anophelines collected by Almeida and Deane (1970).

Deane et al. (1971) observed that near the Tracajatuba River, an area located $100 \mathrm{~km}$ from Serra do Navio, where $16.6 \%$ of monkeys were infected with $P$. brasilianum, both An. nuneztovari and An. oswaldoi were rare (only $3.2 \%$ and $4.7 \%$ of the total, respectively), but An. triannulatus accounted for $63.7 \%$ of the anophelines collected. Similarly, Deane and Ferreira-Neto (1973) reported from Cabeceira Grande, State of Tocantins, that $8.1 \%$ of monkeys were infected with $P$. brasilianum and $70 \%$ of the collected anophelines were An. triannulatus. This mosquito species has been detected in all simian malaria areas surveyed in the Brazilian Amazon, but at most sites its den- 
sity was low or moderate, except for the two localities mentioned above (Deane et al. 1968, 1971, Almeida \& Deane 1970, Ferreira Neto et al. 1970, Deane \& Ferreira Neto 1973).

Brazilian species of monkeys and marmosets live predominantly in the forest canopy where the anopheline vector of simian malaria must also take most of its blood meals. This behavior suggested to Deane et al. (1969) that An. cruzii was the vector of both $P$. brasilianum and $P$. simium in south and southeast Brazil.

The field work performed in Balbina was restricted to short periods in September and October of two adjoing years. At that time, the most common anophelines, An. oswaldoi and An. nuneztovari, were slightly more numerous in the canopy than near the ground. One of the acrodendrophilic anopheline, An. mediopunctatus, was not abundant during that period of the year in Balbina. On the other hand, An. mediopunctatus was the most common and acrodendrophilic anopheline in Samuel and its preference for the high levels of the vegetation in simian malaria areas has already been demonstrated (Deane et al. 1971, Deane 1992) (Table III, Fig. 3).

Previously, An. oswaldoi has been shown to feed preferently in the canopy only in Cabeceira Grande (Deane \& Ferreira Neto 1973). This anopheline was more common in ground collections at Samuel (Table III, Fig. 3) as well as in Trinidad and other localities in Brazil (Aitken et al. 1968, Deane et al. 1971). An. oswaldoi has shown no preference with regard to vertical distribution or tended to be slightly acrodendrophilic, as it was in Balbina, in three other simian malaria areas in the Brazilian Amazon (Deane et al. 1968, 1971, Ferreira Neto et al. 1970).

In contrast to Balbina and Samuel where An. nuneztovari was slightly acrodendrophilic, the species was previously collected in larger numbers near the ground, e.g. by Deane et al. (1971) at Serra do Navio (95.8\% on the ground), at Tracajatuca $(67.1 \%)$ and at Porto Mauá (59.4\%). Although feeding height preferences of An. oswaldoi and An. nuneztovari may vary from site to site, their abundance within the forest (Fig. 1) may suggests their possible involviment in simian malaria at Balbina.

Other anophelines in Samuel, the common An. shannoni and the rare Ch. bonneae, showed a marked preference for biting at the forest canopy. The acrodendrophilic behavior of these species was also observed by Deane et al. $(1953,1968,1971)$ and Ferreira Neto et al. (1970) in several Amazonian areas with and without simian malaria.

Few mosquito surveys were conducted previously at Balbina and Samuel and in their surroundings. Chagas et al. (1982) reported the presence of
An. darlingi, An. nuneztovari and An. oswaldoi in Balbina at the beginning of the dam construction. When the Uatumã River was dammed, flooding of the forest provided extensive breeding sites for $A n$. oswaldoi, which became very abundant (Eletronorte 1988).

The first anopheline survey at Samuel was carried out by Deane (1947) who found 30 An. darlingi and 2 An. nuneztovari indoors, trapped in bednets, during the day. During the construction of the Samuel Dam, An. oswaldoi, An. mediopunctatus, An. nuneztovari were collected near the Jamari River, but An. darlingi was still the predominant mosquito in cleared areas, accounting for $90-100 \%$ of the total captured (Tadei 1985, 1986). Most of the mosquito captures in the present survey were carried out within Samuel's forest in contrast to those performed by Deane (1947) and Tadei (1985, 1986) who worked essentially in man-made or disturbed environments.

The few hours spent with captures conducted in anthropic environments outside the forest in both Balbina and Samuel (Tables I, IV) confirmed the results of hundreds of hours of anopheline collections that we have been performing in the Amazon, with regarding to the anopheline fauna constitution and the synanthropy of An. darlingi (Lourenço-de-Oliveira et al. 1989, 1994).

During the last three decades, ambitious colonization projects in the Brazilian Amazon were responsible for progressive changes in the landscape. The forest was cleared and replaced to pastures and plantations. With the modifications in the landscape several anopheline species commonly reported in the past have been rare in the present surveys. Concomitantly, An. darlingi became the predominant or practically the only species in the anthropic environments. It became the most synanthropic anopheline in the Amazon, as observed at Balbina, Samuel and all over the region (Tadei et al. 1988, Lourenço-de-Oliveira et al. 1989, 1994, Deane 1989, Klein \& Lima 1990, Lourenço-deOliveira 1994). Obviously the sylvatic anophelines deprived from their natural blood feeding sources among wild animals may leave the forest and invade the open fields, i.e. the anthropic environment. There, they attack mostly domestic animals, while $A n$. darling $i$ is the predominant species feeding on man (Deane et al. 1948, Lourenço-de-Oliveira et al. 1989, Klein \& Lima 1990, Oliveira-Ferreira et al. 1992).

An. darlingi may take blood in the forest, even near the canopies. Deane et al. (1953) collected $19.4 \%$ and $11.8 \%$ of An. darlingi females at $10 \mathrm{~m}$ and $15 \mathrm{~m}$, respectively, versus $50.6 \%$ near ground in a forest where simian malaria has never been detected, in Belém, State of Pará. This forest sur- 
rounds one of the principal breeding sites of the species in the area. Lourenço-de-Oliveira et al. (1989) showed that only $6.8 \%$ of the total anophelines collected into a small patch of forest near Ariquemes, State of Rondônia belonged to this species, although there were numerous breeding places in the area.

Species belonging to the An. albitarsis complex, as An. marajoara, are essentially zoophilic mosquitoes that breed and feed outside the forest, where it was not collected at both Balbina and Samuel, confirming previous studies performed by Deane et al. (1948), Lourenço-de-Oliveira and Heyden (1986), Lourenço-de-Oliveira et al. (1989), Rosa-Freitas et al. (1990), Oliveira-Ferreira et al. (1992), Forattini et al. (1993).

We conclude that neither An. darlingi nor $A n$. marajoara can be suspected as vector of simian malaria among monkeys in the forest nor from monkeys to man in the Brazilian Amazon. For the same reason, i.e. because An. darlingi is better adapted to the anthropic environments such as the open fields in the rural areas, cleared river margins and proximity to the secondary woods and recently cleared forests, it is the primary vector of the human malaria throughout this region (Deane 1986, 1989, Lourenço-de-Oliveira 1989, Lourenço-de-Oliveira et al. 1989, Oliveira-Ferreira et al. 1990). On the other hand the anopheline vectors of $P$. brasilianum in the Amazon are likely to be among the most abundant, sylvatic and canopy feeders at Balbina and Samuel: An. mediopunctatus, An. nuneztovari, An. oswaldoi, An. triannulatus and An. shannoni.

\section{ACKNOWLEDGEMENTS}

To "Centrais Elétricas do Norte do Brasil SA" (ELETRONORTE)" for support in the field, Laboratories of Entomology - "Fundação Nacional de Saúde" (FNS), from the states of Rondônia and Amazonas, and "Instituto de Medicina Tropical de Manaus", for the help in the collections of anophelines and Prof. NM Serra Freire for help in the statistical analysis.

\section{REFERENCES}

Aitken THG, Worth CB, Tikasingh ES 1968. Arbovirus studies in Bush Bush forest, Trinidad, W.I., September 1959 - December 1964. III. Entomological Studies. Am J Trop Med Hyg 17: 253-268.

Almeida FB, Deane LM 1970. Plasmodium brasilianum reencontrado em seu hospedeiro original, o macaco uacari branco, Cacajao calvus. Bol Inst Nac Pesq Amazonia (Patologia Tropical) 4: 1-9.

Arruda ME, Nardin EH, Nussenzweig RS, Cochrane AH 1989. Sero-epidemiological studies of malaria in indian tribes and monkeys of the Amazon basin of Brazil. Am J Trop Med Hyg 41: 379-385.

Chagas JAC, Barroso MAB, Amorim RDS, Robles CRQ 1982. Controle da malária em projeto hidrelétrico no estado do Amazonas. Rev Brasil Malariol D Trop 34: 68-81.

Deane LM 1947. Observações sobre a malária na Amazônia brasileira. Rev Serv Esp Saúde Públ 1: 360.

Deane LM 1976. Epidemiology of simian malaria in the American Continent. PAHO Scientific Publ 317: 144-163.

Deane LM 1986. Malaria vectors in Brazil. Mem Inst Oswaldo Cruz 81 (Supl. II): 5-14.

Deane LM 1989. A cronologia da descoberta dos transmissores da malária na Amazônia brasileira. Mem Inst Oswaldo Cruz 84: 149-156.

Deane LM 1992. Simian malaria in Brasil. Mem Inst Oswaldo Cruz 87 (Supl. III): 1-20.

Deane LM, Ferreira Neto JA 1973. Malária de macacos no Estado de Goiás, Brasil: Encontro de Guaribas, Alouatta caraya, infectados com Plasmodium brasilianum. Rev Inst Med Trop São Paulo 15: 107111.

Deane LM, Causey OR, Deane MP 1947. Chave ilustrada para a identificação de trinta e cinco espécies de anofelinos das regiões Nordestina e Amazônica do Brasil pelos caractéres da fêmea, com notas sôbre os transmissores da malária (Diptera, Culicidae). Rev Serv Esp Saúde Públ 1: 309-336.

Deane LM, Causey OR, Deane MP 1948. Notas sobre a distribuição e a biologia dos Anofelinos das Regiões Nordestina e Amazônica do Brasil. Rev Serv Esp Saúde Públ 1: 827-965.

Deane LM, Damasceno RG, Arouck R 1953. Distribuição vertical de mosquitos em uma floresta dos arredores de Belém , Pará. Folia Clínica et Biol 20: 101-110.

Deane LM, Deane MP, Ferreira Neto JA, Almeida FB 1971. On the transmission of simian malaria in Brazil. Rev Inst Med Trop São Paulo 13: 311-319.

Deane LM, Ferreira Neto JA, Cerqueira NL, Almeida FB 1968. Studies on monkey malaria in the vicinity of Manaus, State of Amazonas, Brazil. Rev Inst Med Trop São Paulo 10: 335-341.

Deane LM, Ferreira Neto JA, Deane MP, Silveira IPS 1970. Anopheles (Kerteszia) cruzi, a natural vector of the monkey malaria parasites, Plasmodium simium and Plasmodium brasilianum. Trans $R$ Soc Trop Med Hyg 64: 647.

Deane LM, Ferreira Neto JA, Okumura M, Ferreira MO 1969. Malaria parasites of brazilian monkeys. Rev Inst Med Trop São Paulo 11: 71-86.

Eletronorte 1988. Relatório da Operação Muiraquitã. Min Minas e Energia, Brasília, 93 pp.

Faran ME, Linthicum KJ 1981. A handbook of the Amazonian species of Anopheles (Nyssorhynchus) (Diptera: Culicidae). Mosq Syst 13: 1-81.

Ferreira Neto JA, Deane LM, Carneiro EWB 1970. Infecção natural de guaribas, Alouatta belzebul belzebul (L., 1766), pelo Plasmodium brasilianum Gonder \& Berenberg-Gossler, 1908, no Estado do Maranhão, Brasil. Rev Inst Med Trop São Paulo 12: 169-174.

Forattini OP, Kakitani I, Massad E, Marucci D 1993. Studies on mosquitoes (Diptera: Culicidae) and 
anthropic environment. 2 - Immature stages research at rice irrigation system location in South-Eastern Brazil. Rev Saúde Públ 27: 227-236.

Klein TA, Lima JBP 1990. Seasonal distribution and biting patterns of Anopheles mosquitoes in Costa Marques, Rondônia, Brazil. J Am Mosq Control Assoc 6: 700-707.

Lal AA, Cruz VF, Collins WE, Campbell GH, Procell PM, McCutchan TF 1988. Circumsporozoite protein gene from Plasmodium brasilianum. Animal reservoirs for human malaria parasites? J Biol Chem 263: 5495-5498.

Lourenço-de-Oliveira R 1989. Some observations on the mosquitoes of indian settlements in Xingu National Park, Mato Grosso State, Brazil, with emphasis on malaria vectors. Rev Brasil Biol 49: 393-397.

Lourenço-de-Oliveira R 1994 Qual a importância da hematofagia extradomiciliar do Anopheles darlingi, na Amazônia? Rev Patol Trop 23 (Suppl.): 100-101.

Lourenço-de-Oliveira RL, Heyden R 1986. Alguns aspectos da ecologia dos mosquitos (Diptera: Culicidae) de uma área de planície (Granjas Calábria), em Jacarepaguá, Rio de Janeiro. IV. Preferências alimentares quanto ao hospedeiro e freqüência domiciliar. Mem Inst Oswaldo Cruz 81: 15-27.

Lourenço-de-Oliveira RL, Deane LM 1995. Simian malaria at two sites in the Brazilian Amazon. I - The infection rates of Plasmodium brasilianum in nonhuman primates. Mem Inst Oswaldo Cruz 90: 331339.

Lourenço-de-Oliveira R, Guimarães AEG, Arlé M, Silva TF, Castro M, Motta MA, Deane LM 1989. Anopheline species, some of their habits and relation to malaria in endemic areas of Rondônia state, Amazon region of Brazil. Mem Inst Oswaldo Cruz 84: 501-514.

Lourenço-de-Oliveira R, Santos F, Lima DC, Honório NA, Araújo MDR 1994. Avaliação da importância epidemiológica da hematofagia peri e intradomiciliar do An. darlingi e outros anofelinos em áreas endêmicas de malária, em Rondônia. Rev Patol Trop
23 (Suppl): 319.

Oliveira-Ferreira J, Lourenço-de-Oliveira R, Deane LM, Daniel Ribeiro CT 1992. Feeding preference of Anopheles darlingi in malaria endemic areas of Rondônia state - Northwestern Brazil. Mem Inst Oswaldo Cruz 87: 601-602

Oliveira-Ferreira J, Lourenço-de-Oliveira R, Teva A, Deane LM, Daniel Ribeiro CT 1990. Natural malaria infections in anophelines in Rondônia State, Brazilian Amazon. Am J Trop Med Hyg 43: 6-10.

Rosa Freitas MG, Deane LM, Momen H 1990. A morphological, isoenzymatic and behavioural study of ten populations of Anopheles (Nyssorhynchus) albitarsis Lynch-Arribalzaga, 1878 (Diptera: Culicidae) including from the type-locality - Baradero, Argentina. Mem Inst Oswaldo Cruz 85: 275-289

Sudia WD, Chamberlain RW 1962. Battery operated light trap, an improved model. Mosquito News 22: 126-129.

Tadei VP 1985. Estudos de ecologia e controle ambiental na região do reservatório da UHE de Samuel. Impacto do reservatório no aumento de doenças endêmicas - Vetores da malária. Período julho/ dezembro, 1985. CNPq, Brasília, 18pp.

Tadei VP 1986. Estudos de ecologia e controle ambiental na região do reservatório da UHE de Samuel. Impacto do reservatório no aumento de doenças endêmicas - Vetores da malária. Período julho/dezembro, 1986. CNPq, Brasília, 71pp.

Tadei VP, Santos JMM, Costa WLS, Scardana VM 1988. Biologia dos anofelinos amazônicos. XII. Ocorrência de espécies de Anopheles, dinâmica da transmissão e controle da malária na zona urbana de Ariquemes, Rondônia. Rev Inst Med Trop São Paulo 30: 221251.

Wilkerson RC 1988. Notes and redescription of some Anopheles series Arribalzagia holotypes (Diptera: Culicidae) in the British Museum (Natural History). Proc Entomol Soc Wash 90: 411-421. 